
and Grassroots organisations in XXIst Century China

\title{
Low-cost Corporatism?
}

The Chinese Communist Youth League and its Sub-organisations in postMao China

Jérôme Doyon

\section{(2) OpenEdition}

\section{Journals}

Electronic version

URL: http://journals.openedition.org/chinaperspectives/9084

DOI: 10.4000/chinaperspectives.9084

ISSN: 1996-4617

\section{Publisher}

Centre d'étude français sur la Chine contemporaine

Printed version

Date of publication: 8 June 2019

Number of pages: $39-46$

ISSN: 2070-3449

\section{Electronic reference}

Jérôme Doyon, «Low-cost Corporatism? », China Perspectives [Online], 2019-2 | 2019, Online since 10 June 2020, connection on 22 December 2020. URL : http://journals.openedition.org/ chinaperspectives/9084; DOI : https://doi.org/10.4000/chinaperspectives.9084 


\title{
Low-cost Corporatism
}

\section{The Chinese Communist Youth League and its Sub-organisations in post-Mao China}

\author{
JÉRÔME DOYON
}

\begin{abstract}
The Communist Youth League has developed a network of sub-organisations to expand its reach at minimum cost. It exemplifies the low-cost corporatism model. Following this model, mass organisations maintain a corporatist relationship with the Party while diversifying their activities through structures they supervise. These structures also provide them with additional material and human resources. In this configuration, the Communist Youth League maintains an equilibrium between dependence on the Party and attractiveness to young people. However, reforms put forward under Xi Jinping challenge this fragile equilibrium by strengthening Party control over the League and its suborganisations.
\end{abstract}

KEYWORDS: Mass organisations, Communist Youth League, state-society relations, corporatism.

\section{Introduction}

$\mathrm{C}$ an state-society relations in contemporary China still be described as corporatist? Recent studies show that this framework cannot account for the diversity of grassroots organisations in post-Mao China (Fu 2017; Spires 2011). However, it remains widely used to describe the interactions between the Party-state and a wide range of "social organisations" (shehui zuzhi 社会组织) (Hsu and Hasmath 2013), and especially mass organisations (qunzhong zuzhi 群众组织) (Lu 2009). Controlled by the Party, they serve as "transmission belts" for policies, expanding the CCP's power into specific sectors of society (Townsend 1967). Mass organisations hence embody Schmitter's definition of corporatism as:

A system of interest representation in which the constituent units are organized into a limited number of singular, compulsory, noncompetitive, hierarchically ordered and functionally differentiated categories, recognized or licensed (if not created) by the state and granted a deliberate representational monopoly within their respective categories in exchange for observing certain controls on their selection of leaders and articulation of demands and supports (Schmitter 1974: 93).

In practice, even traditional mass organisations have been moving away from a pure corporatist model. Since the 1980s, they have developed new strategies to remain appealing to their constituencies. Jude Howell shows how in the 1980s, the bourgeoning of study groups and associations on gender issues forced the All-China Women Federation (ACWF) to transform itself (Howell 1996). To survive, the ACWF began to develop its own issue-oriented sub-organisations, creating, for example, the Women's Studies Institute. The ACWF therefore found a subtle way to engage with the government on specific issues while accepting Partystate domination (Howell 2000). As they have emerged, the structures created or co-opted by mass organisations have tended to challenge the traditional corporatist order made of singular, compulsory, and non-competitive entities.
As new entities, these structures supervised by mass organisations became a focus of scholarly attention. Yet their parent organisations remain understudied. The China Youth Development Foundation (Zhongguo qingshaonian fazhan jijinhui 中国青少年发展基金会; hereafter CYDF) exemplifies this trend. Several studies analyse the development of this organisation, presented as one of China's most successful NGOs (Lu 2009; Hsu 2017). The role played by the Communist Youth League, which supervises the CYDF, is by contrast overlooked. I bring the mass organisations back to the centre of the picture. In doing so, I unveil what I call the "low-cost corporatism" model. In that model the Party maintains intact corporatist ties with underfunded mass organisations. In turn, these organisations compensate for their lack of resources and expand their reach through sub-organisations.

I focus on the Communist Youth League (gongchanzhuyi qingnian tuan 共产主义青年团; hereafter the League or CYL). It is the Chinese Communist Party's (CCP) central youth organisation and one of the largest political organisations in the world. It is similar in size to the Party, ${ }^{(1)}$ with 87.5 million members by the end of 2015 (Xinhua 2016). The CYL can be found at every level of the Party-state hierarchy and is very active in units with numerous young people, such as schools and universities (Kou 2007; Tsimonis 2018). In addition to its branches, the CYL is the parent organisation of numerous structures linked to youth affairs (Wang and He 2010). I base my analysis on 14 months of field research conducted in Beijing, Nanjing, and Guiyang between 2011 and 2015. Following a snowball sampling, I did 121 interviews with actors affiliated with the CYL at different levels of the polity.

Despite its importance, there are very few studies on the evolution of the CYL in post-Mao China. The few that exist mainly focus on the League's decline. They depict the League as an anachronistic organisation, entirely controlled by the Party and incapable of attracting young people. These studies highlight how the CYL's core activities of political indoctrination are unappealing to young people (Rosen 1985; Tsimonis 2018). They also stress that the CYL has not managed to have as much influence on policymaking as other mass organisations (Tsimonis forthcoming). Overall, these studies rightly point to the CYL's weaknesses and its inherent tension between Party

1. The CCP had close to 88.75 million members by the end of 2015 (Financial Times 2016). 
control and attractiveness to young people. However, if in such a declining state, how can the CYL still be appealing to young Chinese and recruit more than 40 million volunteers over a decade (2001-2012) (China Youth Daily 2013)? I argue that despite its lack of autonomy and resources, the CYL has managed to maintain a certain level of hegemony over youth activities by coordinating a network of sub-organisations. The League hence embodies the low-cost corporatism model.

To tackle these issues, I first detail the structural weakness of the League in its corporatist relation with the Party. Second, I review the changes in the League's principal activities, and how it frames them differently in the postTiananmen era to attract young people. Third, I highlight the low-cost corporatism model and the growing importance of the League's sub-organisations in the post-Mao era. I argue that the League partially solved its fundamental tension between appeal and control by developing a network of sub-organisations, which allows it to expand its reach at limited cost. Finally, I turn to the reforms implemented under Xi Jinping to show how they challenge the existing and fragile equilibrium. The changes go against the low-cost corporatism model as they limit the CYL's control over sub-organisations.

\section{The Party's assistant and reserve force}

The Chinese Communist Youth League organised its first National Congress in 1922. (2) The Party rapidly took control over the organisations. In 1922, the Party issued a "Resolution on the question of the youth movement" that limited the League's autonomy from the CCP (Graziani 2014). As a result, the CYL became the Party's "assistant" (zhushou 助手) (National Congress of the Communist Youth League 2013). It was a crucial force in the CCP's struggle for power, and after 1949 it was transformed into an instrument to manage young people's activities. During the Cultural Revolution, the CYL was accused of bourgeois revisionism together with core elements of the Party bureaucracy and stopped its operations in 1966 (Graziani 2014; Healy 1982). The central CYL organisation was re-established only in 1978 (Healy 1982).

In the 1980s, reformers thought that a loosening of Party control was essential for the League to remain relevant to young people. They argued that with the decreasing ideological hegemony of the CCP and the emergence of new channels of social mobility in the 1980s, the CYL had progressively lost its control over Chinese youth (Rosen 1985). Columns in the official press discussed the League's right to "conduct independent activities" to be adaptive to young people's needs (Ceng, Zhu and Zhang 1980). A reform was put forward in 1988 to make the CYL, along with other mass organisations, more autonomous in its activities. These debates highlight the League's core tension between Party control and autonomy in order to be more appealing to young people. This tension permeates mass organisations more broadly (see Froissart et al. and Zhou's article in this issue). However, the reform plan was set aside after the suppression of the Tiananmen movement in 1989 (Goldman 1994). The CCP in December 1989 issued a document calling for a strengthening of Party control over its three major mass organisations (Central Communist Party 1989). The little autonomy the CYL had in the 1980s disappeared.

At the same time, the Soviet precedent led the CCP to be cautious with how it dealt with the CYL in the context of a liberalising economy. Maintaining tight control over the CYL appeared a way to prevent a scenario similar to what happened to the Soviet Youth League, the Komsomol, in the 1980s. Like the CYL, the Komsomol was under strict Party control. The situation changed in the 1980s under Gorbachev. It was reorganised and gained substantial autonomy as local units of the organisation took charge of their budgets. According to Solnick, this led to a "bank run" phenomenon in 1987: local Komsomol officials started to use the organisation's resources to develop local businesses (Solnick 1998). With the development of the "Komsomol economy," young cadres increasingly distanced themselves from the Party-state, which accelerated the disintegration of the organisation. As they were among the first to profit from the USSR's liberalising economy, many of them later became major oligarchs.

All of the CYL officials I interviewed highlighted the League's "lack of power and funds" (wuquan wuqian 无权无钱). In addition to controlling its agenda, the CCP selects the CYL leaders at all echelons. At the central level, while the CYL Central Committee formally elects the League's secretaries, it is actually the CCP Politburo Standing Committee that selects them. This configuration is replicated at the lower levels of the organisation.

The CYL also lacks coherence. The CYL at every level is dependent on the Party, and the upper-level CYL units only have a secondary supervision function. As explained by a Central CYL School staff member:

A major problem for the CYL is that it cannot have an integrated work plan. The Central CYL policies are only partially implemented at the local levels as the upper echelons have no power over officials' promotions (...). If a local CYL committee must choose between conflicting orders given by the upper-level CYL committee and by the local CCP committee, it will follow the Party. ${ }^{(3)}$

Chinese specialists of the CYL widely share this diagnosis. For example, Zheng Changzhong 郑长忠, a former CYL official now based at Fudan University, warns that the CYL is marginalised at the local level because local CYL officials do not adequately follow central CYL instructions (Zheng 2008). This is far from a new issue, as already in 1980 the CYL admitted that $30 \%$ of its 2.2 million units countrywide were poorly organised or paralysed (Rosen 1985).

The CYL has few sources of revenue. The day-to-day functioning of the organisation relies on the membership dues it collects, as well as funds from the Party-state. At every echelon the CYL premises and the salaries of its officials are funded by the state, similarly to a government office. Grassroots units collect the membership dues and transmit a portion to the higherlevel CYL units, up to the central level. The amount paid depends on the member's salary (Central Communist Youth League 1994). A figure for the total amount collected every year is hard to estimate. It remains in any case a funding channel of lesser importance than the money coming from the state. ${ }^{(4)}$

Beyond the funding of its day-to-day activities, the CYL can collect additional resources for specific events. It can, for instance, get public funds for the organisation of major activities, as its involvement in the 2008 Olympic Games, ${ }^{(5)}$ or it can raise money from the private sector through various suborganisations, for charity projects in particular. To fund specific activities the CYL can finally rely on sponsorship from its affiliated firms, such as the

\footnotetext{
2. It was then named the Socialist Youth League. In practice, its first cell was created in 1920.

3. Interview with a Central CYL School staff member, Central CYL School, Beijing, 25 June 2013.

4. Interview with a CYL official in a provincial-level state-owned enterprise, Nanjing, 27 June 2012; interview with district-level CYL official, Haidian District, Beijing, 25 June 2013.

5. Interview with former city-level CYL official, Nanjing, 14 December 2011.
} 
Table 1 - The extension of CYL membership and limits of its managing capabilities (1949-2013) (6)

\begin{tabular}{|c|c|c|c|}
\hline $\begin{array}{c}\text { CYL Congress } \\
\text { (year) }\end{array}$ & CCP members & CYL members & $\begin{array}{c}\text { CYL cadres } \\
\text { (full time) }\end{array}$ \\
\hline $6^{\text {th }}(1949)$ & 4.5 million & 190000 & missing \\
\hline $7^{\text {th }}(1953)$ & 6.4 million & 9 million & missing \\
\hline $8^{\text {th }}(1957)$ & 11 million & 23 million & 80,000 \\
\hline $9^{\text {th }}(1964)$ & 18 million & 32 million & missing \\
\hline $10^{\text {th }}(1978)$ & 36 million & 48 million & 150,200 \\
\hline $11^{\text {th }}(1982)$ & 39 million & 48 million & 184,716 \\
\hline $12^{\text {th }}(1988)$ & 47 million & 56 million & 208,027 \\
\hline $13^{\text {th }}(1993)$ & 53 million & 56 million & 227,546 \\
\hline $14^{\text {th }}(1998)$ & 61 million & 68 million & 213,695 \\
\hline $15^{\text {th }}(2003)$ & 68 million & 69 million & 183,000 \\
\hline $16^{\text {th }}(2008)$ & 75 million & 75 million & 190,000 \\
\hline $17^{\text {th }}(2013)$ & 85 million & 89 million & 250,000 \\
\hline
\end{tabular}

publishing house China Youth Press for cultural events, or the "youth travel agencies" for projects with touristic implications. ${ }^{(7)}$

The CYL is not rich, even by comparison with other mass organisations. The 2015 budget of the central CYL (583 million RMB) was only $26.4 \%$ of the 2015 budget of the All-China Federation of Trade Union (2 billion RMB) (Central Communist Youth League 2015; All-China Federation of Trade Unions 2015). At the grassroots level, the annual working budget for a county-level CYL committee is often less than 50,000 RMB, despite regulations setting the minimum yearly budget at 100,000 RMB (China Youth Daily 2012). It mainly covers cadres' salaries and operating fees. ${ }^{(8)}$

Human resources are also limited. While CYL membership has dramatically increased over the years, the number of full-time officials has not grown correspondingly (Table 1). As the Party's "reserve force" (houbeijun 后备军), the Youth League is responsible for recruiting young members, between 14 and 28 years old (National Congress of the Communist Youth League 2013). After being screened and trained, some of them eventually become CCP members. According to the model of "Party-led League-building," the League follows the Party's organisational expansion strategy (National Congress of the Communist Youth League 2013). The CYL has managed to widely expand its membership in the post-Mao era: Since 1982, it has comprised about $25 \%$ of Chinese young people between 14 and 28 years old, compared with 20\% in the 1950-1960s (Healy 1982; Pringsheim 1962).

By contrast, the number of CYL officials dropped in the 1990s as the restructuring of state-owned enterprises led to the dismantlement of many CYL units (Research team of the Central Communist Youth League 2001). The number of CYL officials then started to increase again in the 2000s, but the ratio of official per member remains much lower than in the 1980s. There are many fewer CYL cadres than CCP cadres. In 2013, the CYL had 250,000 full-time officials for 89 million members, while the CCP had 27 million officials for 85 million members (Cabestan 2014: 403). These figures are not entirely comparable, as Party and state officials are hardly separable, but they indicate the CYL's lack of managing capabilities.

In its corporatist relationship to the Party, the CYL is in a situation of organisational "juniority" (Tsimonis 2018): it is unfavourably embedded in Party-state hierarchies and lacks resources. Against this background, how does the CYL remain appealing to young people?

\section{Diversifying the League's activities: Domination over the volunteer sector}

The Tiananmen movement symbolised the CYL's failure to manage young people (Li 2007). In the post-1989 era, therefore, the CYL tried to remain attractive to young people by adapting its activities to the evolving socioeconomic situation. The restructuring of state-owned enterprises announced in 1997 created a significant unemployment problem, and the Party-state called upon the mass organisations to help laid-off workers find new jobs (Hu 2000). The CYL in 1998 launched the "Chinese Young Entrepreneurs Operation." It provided training and financial help to many entrepreneurs as a way to curb unemployment. Between 1998 and 2004, it trained two million young entrepreneurs and provided financial help to 200,000 (Shen 2009). From the late 1990s onwards, environmental protection also emerged as a key public issue and the CYL became active in this arena. The League, together with the central government, in 1999 launched the "Mother River Protection Operation." By 2005, it had collected 250 million RMB, and 300 million young volunteers had participated in the decontamination of the country's rivers (Shen 2009).

The "Young Volunteers Operation" launched in 1993 is the best embodiment of the CYL's efforts to present itself as more modern and inviting. Its goal is to recruit young volunteers and to channel them into a variety of poverty alleviation, education assistance, and environment protection projects. In 1994 the central CYL founded the Chinese Young Volunteers Association and laid out the foundations for a nationally structured system of youth volunteering. The League created volunteer associations at all levels of the polity and established domination over most state-sanctioned volunteering activities (Palmer and Ning forthcoming; Xu 2012). As mentioned in 2010 by Lu Hao, then Central CYL First Secretary: "Youth volunteering is an extremely valuable working brand created by the Communist Youth League" (quoted in Xu 2012: 98).

The volunteer operation included several projects over the years, such as the "Chinese Youth Volunteers Poverty-Elimination Relay Project" initiated in 1996 to improve educational and medical services in poor counties, and the "One-helps-One" project of 1994 which assists the elderly and disabled populations (Hu 2013). Between 2010 and 2013, the League mobilised five million volunteers to take part in the "CYL Volunteering Operation to Take Care of the Children of Rural Migrant Workers" (China Youth Daily 2013). The CYL also recruited volunteers for disaster relief operations and large international events. The Sichuan earthquake of 2008 mobilised more than four million volunteers, and 1.7 million volunteers took part in the Olympic Games that same year (Chong 2011). After establishing a formalised registering system in 2001, the League enlisted more than 40 million volunteers (China Youth Daily 2013).

While these activities appear apolitical, they have a clear political objective. The League launched the Young Volunteers Operation as an attempt to regain control over young people after the 1980s and the Tiananmen mobilisations (Rosen 1992). Already in the early 1980s, CYL officials were

6. The numbers reported at each CYL congresses reflect the situation of the organisation at the end of the previous year. Sources: Central Communist Youth League website (2018); Xinhua (2013); Li (2013); Healy (1982); Gore (2011); Zhang (2013).

7. Interview with provincial-level CYL official, Nanjing, 10 March 2015; interview with city-level CYL official, Guiyang, 20 January 2015; interview with district-level CYL official, Shunyi District, Beijing, 19 November 2015

8. Interview with city-level CYL official, Guiyang, Guizhou, 14 January 2015; interview with a countylevel CYL official, Shijiazhuang, Hebei, 11 June 2015. 
complaining about the increasing influence of "Western concepts" on young people (Ch'i 1991). In 1993, Li Keqiang, then CYL Central Committee First Secretary, launched the Volunteers Operation to tackle this issue. According to a former official active in the CYL central organisation at the time, it has primarily been seen as a smart way to bring more young people within the League's grasp. ${ }^{(9)}$ As Bin Xu's work on civic engagement following the Sichuan earthquake shows, the Party-state and the CYL use the framework of volunteering to channel individuals toward a common goal, despite the variety of reasons they may have to participate (Xu 2017). As explained in 2003 by Yuan Baocheng, then Secretary of the Shenzhen Municipal Youth League Committee: "In order to more effectively bridge and link between the Party and youth, we can make a reference to the operation mechanism of NGOs in developed countries, and extend the work sphere of the CYL" (quoted in Xu 2012: 98).

Studies underscore the continuity between the Volunteers Operation and other mobilisation campaigns such as "Learn from Lei Feng" (Palmer and Ning forthcoming). This operation also exemplifies how the CYL uses suborganisations, in this case the Young Volunteers Association, to develop new activities and frame them differently. The CYL also uses the funds raised by these sub-organisations to compensate for its lack of resources. While in 2012 the CYL's annual budget reached only 1 million RMB, its subordinate Young Volunteers Association had twice as much at its disposal. The CYL uses these resources to recruit and expand its volunteering activities. ${ }^{\left({ }^{10}\right)}$ As I show in the following section, this strategy allows the CYL to diversify its activities despite its lack of autonomy and resources.

\section{Low-cost corporatism}

The Communist Youth League has been at the centre of a network of youth organisations since the early years of the People's Republic of China. In 1949 it established or reshaped youth organisations to target young people outside its reach. The main one was the All-China Federation of Democratic Youth: as the Youth League targeted "politically advanced" youth, the CCP saw the need for a broader organisation aimed at supervising young people more widely. The All-China Federation of Democratic Youth was thus created as an umbrella organisation encompassing other youth groups, including the Youth League but also the All-China Student Federation and the Young Pioneers of China - dedicated to children from six to 14 years old (Barnett 1951). Its First Congress was held in Beijing in 1949. In 1958 it became the All-China Youth Federation (ACYF) and still exists as such today (Hu 2013).

The CYL is officially defined as the ACYF's "core" (hexin 核心) (Congress of the All-China Youth Federation 2010). The ACYF Chairman is at the same time the CYL Central Committee's Executive Secretary, the League's number two. The ACYF Secretary-General, in charge of day-to-day activities, also heads the CYL United Front Work Department. The ACYF's dependence on the League is replicated at the local level (Kou 2007).

The ACYF is a consultative body for the CYL and it does not have its own activities, funding, or organisational life (Hu 2013). It is a United Front organisation for the CYL and its mission is to liaise with non-communist young people (Pringsheim 1962). It allows the CYL to expand its influence beyond its membership, and to co-opt successful businesspeople or religious leaders. CYL officials also use it as a public relations platform: they present themselves as ACYF cadres to tone down the political nature of their position when meeting foreigners. ${ }^{(11)}$ Overall, the CYL's relationship with the ACYF mirrors the CCP's relationship with the Chinese People's Political Consultative Conference. This advisory body symbolises the Party's United Front strategy: it is a discussion platform between the CCP and non-Party groups, such as economic, intellectual, or religious elites (Groot 2004).

Beyond the ACYF and other youth organisations established in the early years of the People's Republic of China, the CYL has since the 1980s developed a web of sub-organisations to diversify its activities. The China Youth Development Foundation (CYDF) exemplifies this strategy. Founded in March 1989, it quickly launched "Project Hope" (Xiwang gongcheng 希望工程), aimed at improving primary education in the poorest regions of China. The project started by sponsoring the reconstruction of a school in Anhui Province, which became the first Hope primary school. Project Hope then gained momentum and began to attract considerable private funding (Wang 1999). Numerous companies donate to the CYDF, often through their internal CYL committees (Tsimonis 2017). According to its website, the CYDF raised 14 billion RMB to help fund the education of 5.8 million students between 1989 and 2017. It participated in the renovation of 19,000 primary schools and 29,000 libraries, and trained 106,000 rural teachers. ${ }^{(12)}$

While often presented as an NGO, the CYDF can hardly be described as one (Lu 2009; Hsu 2017). It is under the direct control of the CYL leadership; the CYDF president has always been a CYL leader. Xu Yongguang 徐永光, then Organisation department director of the CYL, headed the ACYF at its creation. He Junke 贺军科, first secretary of the CYL Central Committee, is its current president. ${ }^{(13)}$ At the local level, CYL committees manage CYDF branches, and the two organisations generally share offices. Based on the close link between the two organisations, CYL cadres tend to regard CYDF activities as another League project. (14) Along these lines, Lu Yiyi showed how the relationship between the CYL and the CYDF has been mutually beneficial. The CYDF has used the protection and the networks of the League to raise funds and to develop projects that local administrations sometimes opposed. At the same time the success of Project Hope has helped to improve the CYL's public image (Lu 2009). (15)

Local-level CYL committees follow the same model and establish their own initiatives. The "Chunhui Project" (Chunhui xingdong 春晖行动), developed in Guizhou, is an excellent example of such adaptation. In 2004, the Guizhou Province CYL committee launched this poverty relief project targeting rural and national minority areas. The provincial-level CYL set up an organisation to supervise its implementation. In 2007 it became the Guizhou Province Chunhui Project Development Centre. Through its grassroots branches, the CYL contacts key actors and puts them in touch with charity organisations or investors. Among other things, it provides scholarships for rural students and support packages

9. Interview with a former Central CYL official, Central CYL School, Beijing, 18 March 2015.

10. Interview with a district-level CYL official, Haidian District, Beijing, 16 June 2012.

11. Interview with an ACYF representative, Nanjing, 4 April 2015.

12. CYDF website, http://www.cydf.org.cn (accessed on 4 April 2019).

13. Xu Yongguang's official CV, http://www.xuyongguang.cn/category/86; He Junke's CV, http://news.sina.com.cn/0/2018-06-29/doc-iheqpwqz1718928.shtml (both accessed on 2 April 2019).

14. Interview with a district-level CYL official, Haidian District, Beijing, 16 June 2012.

15. Interview with a provincial-level CYL official, Nanjing, 10 March 2015; interview with a city-level CYL official, Guiyang, 20 January 2015; interview with a district-level CYL official, Shunyi District, Beijing, 19 November 2015 
for local entrepreneurs. ${ }^{(16)}$ The funds come primarily from companies, and some of them set up their own initiatives within the overall Chunhui project. The Maotai liquor company, for example, provides "Maotai student scholarships." (17)

The CYL uses sub-organisations to increase its resources. As it cannot raise private funds directly, it uses these structures to do so. ${ }^{(18)} \mathrm{A}$ Central CYL school staff member mentioned how "the CYL has no money, but it has rich charities associated with it." (19) The CYDF, for instance, raises much more money than the CYL receives from the state or its own members. In 2014 the CYDF raised 521 million RMB, ${ }^{(20)}$ while the central CYL budget was 471 million (Central Communist Youth League 2014). This is also true at the local level. In 2014 in Guizhou Province, the local CYDF raised 150 million RMB, ${ }^{(21)}$ compared with a CYL budget of 100 million (Guizhou Provincial Communist Youth League 2016). That same year, the Chunhui Project raised another 7 million RMB for poverty-relief activities. ${ }^{(22)}$ While these projects flourish in the under-developed province of Guizhou, fundraising activities are also important in more affluent provinces. In jiangsu in the mid-2010s, the CYDF raised about 20 million RMB annually, ${ }^{(23)}$ while the CYL budget was around 55 million (Jiangsu Provincial Communist Youth League 2016). At the local level these funds are directly managed by CYL committees, and some are directly used for the League's functioning rather than for CYDF projects themselves (Hsu 2017). As Lu Yiyi summarises it: "The CYDF costs nothing, while continuously bringing in huge economic and political benefits" (Lu 2009: 49).

The CYL also uses its sub-organisations to access additional human resources when it cannot expand its payroll due to lack of funding or administrative quotas. For example, the Guizhou Province CYL committee has 42 officials on its payroll but also 171 additional cadres working in affiliated structures. It includes staff for the local CYL school and publishing house, but also the local Youth Development Foundation's 15 staff members. (24)

The resources tied to specific projects and sub-organisations can lead to competition across CYL units. The Nanjing 2015 Youth Olympic Games, which took place during my fieldwork, illustrated this dynamic. The Nanjing City CYL took an active part in the event and established a committee in charge of its management. It included about 400 staff members, a large number of them being dispatched CYL officials. The committee was in charge of recruiting and managing around 20,000 volunteers for the event. ${ }^{(25)} \mathrm{Ac}-$ cording to my interviewees, the situation led to open competition with the jiangsu provincial CYL as it tried to gain control over the organisation of the event and the funds provided by the central government. (26)

In the low-cost corporatism configuration, the CYL has little autonomy from the Party and few resources, but it develops a network of organisations to expand its reach. As my interviewees repeatedly observed, the CYL functions as a "platform" that connects and supervises many subsidiary organisations. ${ }^{(27)}$ It echoes the Party's transformation into a "hub-like" organisation, as described by Patricia Thornton (2013). Low-cost corporatism shares some features with traditional forms of corporatism, with the Party-state as the main supervising actor. However, it is more flexible as similar organisations coexist and sometimes compete. This model of low-cost corporatism allows the CYL to remain the Party's assistant while benefitting from the activities of supervised social organisations. The League can therefore maintain an equilibrium between Party control and engagement with young people at limited cost.

\section{Restructuring of the Youth League under Xi Jinping}

Recent developments highlight the CYL's weakening and its decreasing control over its sub-organisations. At its 2018 National Congress, the newly appointed CYL First Secretary, He Junke, stressed that "CYL's work often does not live up to the standards of the new era (...). The CYL still has weak foundations at the grassroots." He also called for strengthening the CYL's "political and vanguard features," which translates into more emphasis on ideological training and stricter recruitment criteria for members (He 2018). As a result, CYL membership dropped to 81 million in 2018, compared to 85 million in 2013 (Xinhua 2018). He Junke's speech is in line with recent criticisms of the League. In 2015, the Central Commission for Discipline Inspection accused the CYL of becoming increasingly "bureaucratic, administrative, aristocratic, and entertainment-oriented" (Central Commission for Discipline Inspection 2016). Also, in a recent book compiling his comments on youth issues, Xi Jinping warned the CYL against "empty slogans" and the risk of becoming an "empty shell." Xi called for a transformation of youth work and a strengthening of Party control over the CYL (Xi 2017).

As a result, the CYL is undergoing an overall restructuring. The CCP Politburo Standing Committee in August 2016 adopted the "Proposal on the Reform of the Central Youth League," which strengthens the Party's control over the League and reforms its leadership organs (Central Communist Youth League 2016a). The restructuring includes "shrinkage at the top and replenishment below," which implies a decrease in full-time CYL personnel at the central and provincial levels, and a parallel increase in staff at the county level. Overall, this reform limits the power of the upper-level CYL organisations and strengthens the CCP's control over it.

This restructuring has been accompanied by a weakening of the CYL's control over sub-organisations. Cuts in the central CYL's budget symbolise this change. The budget was cut by almost half between 2015 and 2016, as the CYL lost part of its control over significant volunteering projects and the attached funding (Central Communist Youth League 2016b). Different ministries have been competing since then to gain control over various volunteering projects. ${ }^{(28)} \mathrm{A}$ similar trend is apparent at the local level. In Guizhou

16. Interview with a city-level CYL official, Guiyang, 20 January 2015; interview with provincial-level CYL official, Guiyang, 14 January 2015

17. China Foundation Centre website, http://www1.foundationcentre.org.cn/Content/Index?bh=1771 (accessed on 3 April 2019).

18. Interview with a district-level CYL official, Haidian District, Beijing, 16 June 2012.

19. Interview with a Central CYL School staff member, Central CYL School, Beijing, 25 June 2013.

20. China Foundation Centre website, http://www1.foundationcentre.org.cn/Content/Index?bh=236 (accessed on 3 April 2019).

21. China Foundation Centre website, http://www1.foundationcentre.org.cn/Content/Index?bh=1778 (accessed on 3 April 2019).

22. China Foundation Centre website, http://www1.foundationcentre.org.cn/Content/Index?bh=1771 (accessed on 3 April 2019).

23. China Foundation Centre website, http://www1.foundationcentre.org.cn/Content/Index?bh=824 (accessed on 3 April 2019).

24. Interview with a city-level CYL official, Guiyang, 20 January 2015; interview with a provinciallevel CYL official, Guiyang, 14 January 2015.

25. Interview with a city-level CYL official, Nanjing, 7 July 2015.

26. Interview with a provincial-level CYL official, Nanjing, 10 March 2015; interview with a city-level CYL official, Nanjing, 13 March 2015.

27. Interview with a provincial-level CYL official, Nanjing, 10 March 2015; interview with a city-level CYL official, Guiyang, 20 January 2015; interview with a district-level CYL official, Shunyi District, Beijing, 19 November 2015; interview with a district-level CYL official, Haidian District, Beijing, 16 June 2012.

28. Interview with a district-level CYL official, Chaoyang District, Beijing, 28 July 2017. 
Province, for example, the local Youth Development Foundation budget was included in the overall CYL budget until 2014, but that is not the case anymore (Guizhou Provincial Communist Youth League 2016). Besides, the Central CYL is losing control over other sources of revenue. The CYL has lost its corporate holdings in China Travel Group and Cachet Pharmaceutical (Yicai 2018). Also, the core of the China Youth University of Political Studies, co-managed by the CYL and the ministry of Education, has been absorbed into the newlyestablished University of Chinese Academy of Social Sciences (Xinhua 2017).

These changes are moving the CYL away from low-cost corporatism. The Party is strengthening its control and challenging the CYL's brokering role. Going back to a more traditional corporatist model, the League is expected to focus on its core political indoctrination function. This may profoundly limit the League's appeal in the long run.

Without the Youth League as an intermediary, the Party can more directly engage with organisations such as the CYDF. This evolution is in line with the broader transformation of state-society relations under Xi linping. More Party control goes hand-in-hand with new regulations to facilitate the development of organisations providing social services. In some predetermined sectors, public welfare and charity in particular, social organisations can now register without a sponsor and engage directly with the Party-state (Shieh 2018).

\section{Conclusion}

Despite the transformations of the reform era, the CYL tries to remain the only game in town and prevent any form of political alternative to emerge. Its lack of autonomy from the Party, organisational coherence, and resources makes this difficult. To remain appealing, it has established a network of sub-organisations and diversified its activities, especially into the welfare sector. Via its sub-organisations, the CYL is also active abroad through volunteering programs or disaster-relief efforts (Jourda in this issue; Graziani and Ceccagno 2016). I apply the term "low-cost corporatism" to this con-

\section{References}

All-China Federation of Trade Unions (Quanguo gonghui 全国工会). 2015. "工会部门预算" (Gonghui bumen yusuan, Budget of the ACFTU). 17 April 2015. http://www.acftu.org/template/10041/file.jsp? cid=809\&aid=90 506 (accessed on 9 April 2019).

BARNETT, Doak A. 1951. "Mass Political Organizations in Communist China." Annals of the American Academy of Political and Social Science 277(September): 76-88.

CENG, Tongrong, ZHU Huilun, and ZHANG Biao. 1980."八十年代青年的 特点你知道吗?" (Bashi niandai qingnian de tedian, ni zhidao ma?, Do you know the characteristics of the 1980s youth?). China Youth, 24 July 1980.

CABESTAN, Jean-Pierre. 2014. Le système politique chinois: un nouvel équilibre autoritaire (The Chinese political system: a new authoritarian equilibrium). Paris: Presses de Sciences Po.

Central Commission for Discipline Inspection (Zhongyang jiwei 中央纪委). 2016. “中央第二巡视组向共青团中央反馈专项巡视情况” (Zhongyang di'er xunshizu xiang gongqingtuan zhongyang fankui zhuanxiang xunshi qingkuang, The $2^{\text {nd }}$ Central Inspection Team gives feedback regarding the circumstances of the special inspection of the Central Communist Youth League). 4 February 2016. http://www.ccdi.gov.cn/special/zyxszt/20 15dsl_zyxs/fgqg_2015dsl_zyxs/201602/t20160219_74595.html (accessed on 20 February 2016).

Central Communist Youth League (Gongqingtuan zhongyang 共青团中央) 2016a. “共青团中央改革方案” (Gongqingtuan zhongyang gaige fang'an, Proposal on the reform of the Central Youth League). 2 August 2016. figuration, which allows the CYL to maintain an equilibrium between Party control and engagement with young people at limited cost.

Low-cost corporatism echoes the model of consultative authoritarianism put forward by Teets, as its indirect control over social organisations allows the Party-state to reap the benefits of their actions (Teets 2014). The lowcost corporatism model can also account for the cooperation between other mass organisations and subsidiary organisations analysed in various studies (Lu 2009; Hsu and Hasmath 2013; Howell 2015). Jude Howell highlights how the Party and its mass organisations subcontract some of their social welfare functions to subordinate organisations. Following a strategy of "welfarist incorporation," the state can "purchases services" so it no longer has to provide them directly (Howell 2015). Following the economic reforms, the Party-state induced mass organisations to take over welfare services it did not provide anymore (Ma 2006). In turn, they relied on their sub-organisations to develop initiatives such as Project Hope and to raise the necessary funds.

The low-cost corporatism configuration nevertheless remains a fragile equilibrium that is currently challenged. Reforms put forward under $\mathrm{Xi}$ Jinping strengthen Party control over the CYL and the League's sub-organisations. The CYL is therefore losing its brokering function. In a traditional corporatist fashion, it is expected to focus on its primary political indoctrination function, which may limit its appeal in the future.

\section{Jérôme Doyon is Departmental Lecturer at the School of Global and Area Studies, University of Oxford}

(http://www.ccsp.ox.ac.uk/dr-jérôme-doyon). His research focuses on Chinese domestic politics: the Party-state apparatus, elite politics, political youth organisations, and the management of ethno-religious minorities (jerome.doyon@gmail.com).

Manuscript received on 12 September 2018. Accepted on 15 April 2019.

Central Communist Youth League (Gongqingtuan zhongyang 共青团中央). 2016b. “共青团中央2016年部门预算” (Gongqingtuan zhongyang 2016 nian bumen yusuan, 2016 Budget of the Central Communist Youth League). 15 April 2016. http://www.ccyl.org.cn/notice/201604/t201 60415_757233.htm (accessed on 9 April 2019).

Central Communist Youth League (Gongqingtuan zhongyang 共青团中央). 2015. “共青团中央2015年部门预算” (Gongqingtuan zhongyang 2015 nian bumen yusuan, 2015 Budget of the central CYL). 17 April 2015. http://www.gqt.org.cn/notice/201504/t20150417_738048.htm (accessed on 9 April 2019).

Central Communist Youth League (Gongqingtuan zhongyang 共青团中央). 2014. “共青团中央2014年部门预算” (Gongqingtuan zhongyang 2014 nian bumen yusuan, 2014 Budget of the central CYL). 18 April 2014. http://www.gqt.org.cn/notice/201404/t20140418_688017.htm (accessed on 9 April 2019).

Central Communist Youth League (Gongqingtuan zhongyang 共青团中央). 1994. “关于团费缴纳和管理使用的规定” (Guanyu tuanfei jiaona he guanli shiyong de guiding, Regulation regarding the payment and management of CYL membership dues). 8 March 1994.

Central Communist Youth League website (Gongqingtuan zhongyang wangzhan 共青团中央网站). 2018. “团历年数据统计汇总” (Tuan linian shuju tongji huizong, Collection of the yearly League statistics). http://dangshi.people.com.cn/GB/242358/242770/17735465.html (accessed on 9 April 2019). 
Central Communist Party (Zhonggong zhongyang 中共中央). 1989."中共 中央关于加强和改善党对工会，共青团，妇联工作领导的通知” (Zhonggong zhongyang, guanyu jiaqiang he gaishan dang dui gonghui, gongqingtuan, fulian gongzuo lingdao de tongzhi, Notice regarding the strengthening and improvement of the Party's control over the work of the ACFTU, the CYL, and the Women's Federation). 12 December 1989.

2013. “中国青年志愿者行动20年报告” (Zhongguo qingnian zhiyuanzhe xingdong 20 nian baogao, Report on the 20 years of the China Young Volunteers Operation). China Youth Daily (Zhongguo qingnianbao 中国青年 报), 5 December 2013.

2012. “创新组织格局抓住活水源头” (Chuangxin zuzhi geju zhuazhu huoshui yuantou, Upgrading the organisational framework, grabbing the water source). China Youth Daily (Zhongguo qingnianbao 中国青年报), 8 February 2012.

CH'I, Hsi-sheng. 1991. Politics of Disillusionment: The Chinese Communist Party under Deng Xiaoping, 1978-1989. Armonk N.Y.: M.E. Sharpe.

CHONG, G. Pak Lei. 2011. "Volunteers as the 'new' Model Citizens: Governing Citizens through Soft Power." China Information 25(1): 33-59.

Congress of the All-China Youth Federation (Zhonghua quanguo qingnian lianhehui daibiao dahui 中华全国青年联合会代表大会). 2010."中华全国 青年联合会章程” (Zhonghua quanguo qingnian lianhehui zhangcheng Charter of the All-China Youth Federation). 24 August 2010.

National Congress of the Communist Youth League (Gongqingtuan quanguo daibiaodahui 共青团全国代表大会). 2013. “中国共产主义青年团章程” (Zhongguo gongchanzhuyi qingnian tuan zhangcheng, Charter of the Chinese Communist Youth League). 20 June 2013.

2016. "Chinese Communist Party's Membership Growth Slows." Financial Time, 30 June 2016. https://www.ft.com/content/3b92a4c4-876d-3d44b547-a4b4fedd8524 (accessed on 9 April 2019).

FROISSART, Chloé, Yan LIU, and Quan MENG. 2019. "Trade-offs Between State Organisations and Workers' Organisations: Chinese Unions in Search of Authoritarian Collective Bargaining." China Perspectives 2(117): 29-38.

FU, Diana. 2017. Mobilizing without the Masses Control and Contention in China. Cambridge: Cambridge University Press.

GORE, Lance. 2011. The Chinese Communist Party and China's Capitalist Revolution: The Political Impact of the Market. New York: Routledge.

GOLDMAN, Merle. 1994. Sowing the Seeds of Democracy. Cambridge, MA: Harvard University Press.

GRAZIANI, Sofia. 2014. "Youth and the Making of Modern China." European Journal of East Asian Studies 13(1): 117-49.

GRAZIANI, Sofia, and Antonella CECCAGNO. 2016. "Chinese Volunteering in Africa Drivers, Issues and Future Prospects." Annali di Ca' Foscari. Serie orientale 52: 297-333.

GROOT, Gerry. 2004. Managing Transitions: the Chinese Communist Party, United Front Work, Corporatism, and Hegemony. New York: Routledge.

Guizhou Provincial Communist Youth League (Gongqingtuan Guizhou shengwei 共青团贵州省委). 2016. “共青团贵州省委2015年部门决算” (Gongqingtuan Guizhou shengwei 2015 nian bumen juesuan, 2015 Accounts of the CYL Guizhou provincial committee). 6 September 2016. http://www.gzyouth.cn/index.php?s=/home/artice/index/id/2517 (accessed on 9 April 2019).

$H E$, Junke 贺军科. 2018. “在中国共产主义青年团第十八次全国代表大会上 的报告" (Zai Zhongguo gongchanzhuyi qingniantuan di shiba ci quanguo daibiao dahui shang de baogao, Report at the $18^{\text {th }}$ National Congress of the Communist Youth League). 26 June 2018.
HEALY, Paul Michael. 1982. The Chinese Communist Youth League, 19491979. Nathan: School of Modern Asian Studies, Griffith University.

HOWELL, Jude. 1996. "The Struggle for Survival: Prospects for the Women's Federation in Post-Mao China." World Development 24(1): 129-43.

HOWELL, Jude. 2000. "Organising around Women and Labour in China: Uneasy Shadows, Uncomfortable Alliances." Communist and Post-Communist Studies 33(3): 355-77.

HOWELL, Jude. 2015. "Shall We Dance? Welfarist Incorporation and the Politics of State-Labour NGO Relations." The China Quarterly 223(September): 702-23.

HSU, Carolyn. 2017. "China Youth Development Foundation: GONGO (Government-Organized NGO) or GENGO (Government-Exploiting NGO)?" In Reza Hasmath and Jennifer Hsu (eds.), NGO Governance and Management in China. London: Routledge.

HSU, Jennifer Y. J., and Reza HASMATH (eds.). 2013. The Chinese Corporatist State: Adaption, Survival and Resistance. London: Routledge.

HU, Xianzhong 胡献忠. 2013. 社会变革中的共青团 (Shehui biange zhong de gongqingtuan, The CYL in a transforming society). Beijing: Chinese Society Press.

LU, Xiaobo. 2000. "The State, Enterprises, and Society in Post-Deng China: Impact of the New Round of SOE Reform." Asian Survey 40(4): 641-57.

Jiangsu Provincial Communist Youth League (Gongqingtuan Jiangsu shengwei 共青团江苏省委). 2016. “2015年度共青团江苏省委决算公开报告” (2015 niandu gongqingtuan jiangsu shengwei juesuan gongkai baogao, 2015 Open accounting report for the jiangsu provincial CYL committee). 25 August 2016. http://www.jiangsugqt.org/xxgk1/article/1248f00.html (accessed on 9 April 2019).

JOURDA, Emmanuel. 2019. "The Ram Union. Emergence of an International NGO Supported by the Party-state." China Perspectives 2(117): 4755.

KOU, Chien-Wen. 2007. "CYL Cadres Rising in the Era of Hu Jintao: Factional Considerations or Organizational Mission of Channeling Cadres." Prospect Journal 3: 77-116.

LI, Yuanchao 李源潮. 2013. “在共青团十七届一中全会上的讲话” (Zai Gongqingtuan shiqi jie yi zhongquanhui shang de jianghua, Speech at the First Plenum of the $17^{\text {th }}$ Congress of the Chinese Communist Youth League). China Youth Daily, 24 June 2013.

LI, Datong. 2007. "China's Youth League Faction: Incubus of Power?" OpenDemocracy, 31 October 2007. https://www.opendemocracy.net/article/ democracy_power/china_inside/youth_league (accessed on 9 April 2019).

LU,Yiyi. 2009. Non-Governmental Organizations in China: The Rise of Dependent Autonomy. London and New York: Routledge.

MA, Qiusha. 2006. Non-Governmental Organizations in Contemporary China: Paving the Way to Civil Society? London and New York: Routledge.

PALMER, David A., and Rundong NING. Forthcoming. "The Resurrection of Lei Feng: Rebuilding the Chinese Party-State's Infrastructure of Volunteer Mobilization." In Elizabeth J. Perry, Xiaojun Yan, and Grzegorz Ekiert (eds.), Ruling by Other Means: State-Mobilized Social Movements. Cambridge: Cambridge University Press.

PRINGSHEIM, Klaus H. 1962. "The Functions of the Chinese Communist Youth Leagues (1920-1949)." The China Quarterly 12(December): 75-91.

Research team of the Central Communist Youth League (Tuan zhongyang ketizu 团中央课题组). 2001. “市场经济条件下共青团组织面临的机遇, 挑 战与对策" (Shichang jingji tiaojian xia Congqingtuan zuzhi mianlin de jiyu, 
tiaozhan yu duice, Opportunities and reactions faced by the CYL organisation in a liberalising economy). China Youth Studies 1: 39-46.

ROSEN, Stanley. 1985. "Prosperity, Privatization, and China's Youth." Problems of Communism 34: 1-28.

ROSEN, Stanley. 1992. "Students and the State in China:The Crisis in Ideology and Organization." In Arthur L. Rosenbaum (ed.), State and Society in China: The Consequences of Reform. Boulder:Westview Press. 167-91.

SCHMITTER, Philippe C. 1974. "Still the Century of Corporatism?" The Review of Politics 36(1): 85-131.

SHIEH, Shawn. 2018. "Remaking China's Civil Society in the Xi Jinping Era." ChinaFile, 2 August 2018. http://www.chinafile.com/reporting-opinion/ viewpoint/remaking-chinas-civil-society-xi-jinping-era (accessed on 9 April 2019).

SHEN, Jianping 沈建平. 2009. 政治学视野下的中国共青团 (Zhengzhixue shiyexia de Zhongguo gongqingtuan, A political science approach to the Communist Youth League). Beijing: China Aerospace Press.

SOLNICK, Steven Lee. 1998. Stealing the State: Control and Collapse in Soviet Institutions. Cambridge: Harvard University Press.

SPIRES, Anthony J. 2011. "Contingent Symbiosis and Civil Society in an Authoritarian State: Understanding the Survival of China's Grassroots NGOs." American Journal of Sociology 117(1): 1-45.

TEETS, Jessica C. 2014. Civil Society under Authoritarianism: The China Model. New York: Cambridge University Press.

THORNTON, Patricia M. 2013. "The Advance of the Party:Transformation or Takeover of Urban Grassroots Society?" The China Quarterly 213(March): 1-18.

TOWNSEND, James R. 1967. Political Participation in Communist China. Berkeley: University of California Press.

TSIMONIS, Konstantinos. 2017. "(De)mobilising and (Mis)representing 'Youth' in the Chinese Workplace: Political Dependency, Generational Subordination and Corporatisation in the Communist Youth League." Journal of Youth Studies 20(10): 1362-79.

TSIMONIS, Konstantinos. 2018. "'Keep the Party Assured and the Youth [Not] Satisfied': The Communist Youth League and Chinese University Students." Modern China 44(2): 170-207.

TSIMONIS, Konstantinos. Forthcoming. The Communist Youth League and Chinese Youth. Amsterdam: Amsterdam University Press.

WANG, Chengzhi. 1999. "Project Hope and the Hope School System in China: A Re-Evaluation." Education Policy Analysis Archives 7(28): 1-18.

WANG, Shaoguang, and jianyu HE. 2010. "Training Ground for Democracy: Associational Life in China." In Zhenglai Deng (ed.), State and Civil Society the Chinese Perspective. Singapore and Hackensack, N.J.:World Scientific. 271-310.
XI, Jinping 习近平. 2017. 习近平关于青少年和共青团工作论述摘编 (Xi Jinping guanyu qingshaonian he gongqingtuan gongzuo lunshu zhaibian, Compilation of Xi Jinping's remarks on youth and the work of the Communist Youth League). Beijing: Central Party Literature Press.

2018. “中国共产主义青年团第十八次全国代表大会在京开幕” (Zhongguo gongchanzhuyi qingniantuan di shiba ci quanguo daibiao dahui zai Jing kaimu, The $18^{\text {th }}$ national Congress of the CYL opens in Beijing). Xinhua 新华, 26 June 2018. http://www.xinhuanet.com/politics/leaders/201806/26/c_1123039647.htm (accessed on 9 April 2019).

2017. “中国青年政治学院本科转至中国社会科学院大学” (Zhongguo qingnian zhengzhi xueyuan benke zhuanzhi Zhongguo shehui kexue xueyuan daxue, The bachelor degrees of the China Youth University of Political Science to be transferred to the University of Chinese Academy of Social Sciences). Xinhua 新华，19 May 2017. http://www.xinhuanet.com /2017-05/19/c_1121003341.htm (accessed on 9 April 2019).

2016. "Over 87 Mln Chinese Communist Youth League Members." Xinhua 新华, 3 May 2016.

2013. "China's Communist Party Membership Exceeds 85 million." Xinhua 新华, 1 July 2013.

XU, Bin. 2017. The Politics of Compassion: The Sichuan Earthquake and Civic Engagement in China. Standford: Stanford University Press.

XU, Ying. 2012. "Chinese Communist Youth League, Political Capital and the Legitimising of Volunteering in China." International Journal of Adolescence and Youth 17(2-3): 95-112.

2018. "State Council to Become Actual Controller of China CYTS Tours, Cachet Pharmaceutical." Yicai, 5 January 2018. https:/www.yicaiglobal.com/ news/state-council-become-actual-controller-china-cyts-tours-cachetpharmaceutical (accessed on 9 April 2019).

ZHANG, Hua 张华. 2013. 中国共产主义青年团职能研究 (Zhongguo gongchanzhuyi qingniantuan zhineng yanjiu, Studies on the functions of the Communist Youth League of China). Beijing: People's Press.

ZHENG, Changzhong 郑长忠. 2008. “关系空间再造的政治逻辑” (Guanxi kongjian zaizao de zhengzhi luoji, The political logic behind the restructuring of social spaces). Contemporary Youth Research 1:21-8.

ZHOU, Yunyun. 2019. "'Being a Good Daughter of the Party'? A Neo-Institutional Analysis of the All-China Women's Federation Organisational Reforms in China's Xi Era." China Perspectives 2(117): 17-28. 